\title{
A Review - Renewable energy based micro-cogeneration and hybrid energy systems
}

\author{
Sonja Kallio, ${ }^{1, *}$ and Monica Siroux ${ }^{1}$ \\ ${ }^{1}$ INSA Strasbourg ICUBE Strasbourg University, France
}

\begin{abstract}
To reduce carbon and greenhouse gas emissions, the more efficient and environmentally friendly energy production in the building sector is required. The deployment of renewable energy based microcogeneration units in the decentralized hybrid energy systems is a part of the solution. The micro combined heat and power (micro-CHP), or co-generation, units produce simultaneously heat and electricity from a single fuel source at high efficiency and close to the consumption point. These units offer significant benefits: reduced primary energy consumption, reduced $\mathrm{CO} 2$ emissions, and avoidance of distribution losses due to central plant and network construction. The objective of this paper is to present a review of available renewable energy based micro-CHP systems and to focus on the biomass and solar based conversion devices. Finally, a novel hybrid renewable energy system is presented by coupling renewable energy sources, such as solar and biomass for micro-CHP.
\end{abstract}

\section{Introduction}

The building sector has a high impact on greenhouse gas emissions and final energy consumption in the European Union (EU) by being the largest energy end-use sector with a share of $41 \%$. [1] The micro combined heat and power (micro-CHP), or co-generation, units produce simultaneously heat and electricity from a single fuel source at high efficiency and close to the consumption point. [2] Micro-CHP systems are operating in the building sector to produce on-site energy for space heating, domestic hot water and electricity demand. Due to the efficient decentralized production of heat and electricity, the overall system efficiency up to $85-90 \%$ can be reached with the micro-CHP units. [3] The microCHP systems can respond to the intrinsic requirements of the residential building sector, such as highly variable thermal and electrical demand loads. The highly variable loads require a short response time which can be provided by micro-CHP systems. [4] The European Parliament has defined the micro-cogeneration to be the units up to an electrical output of $50 \mathrm{~kW}$. [5] However, micro-CHP commonly refers to the units up to $15 \mathrm{~kW}$ of electrical power. [6] The renewable energy based microCHP systems are in the key role in reaching the primary energy and pollutant emissions reduction targets of the EU. [7]

In the literature, several review works have been conducted in terms of renewable energy based microCHP systems [6,8]. In 2017, Martinez et al. [3] published a review article of micro-CHP systems based on renewable energy sources. The work presented different micro-CHP conversion technologies and used fuels. Finally, they focused on the solar energy-based technologies and presented shortly the main micro-CHP systems that coupled renewable energy sources. In 2020, Cheekatamarla et al. [9] presented a review article on the modelling of the micro-CHP system with a focus on combustion engine as a prime mover. They found out that the Annex 42 [10] model was the most used modelling approach.

This paper presents a review of the renewable energy-based micro-CHP systems. First, the available energy conversion devices are presented with renewable energy sources. As a second part, hybrid renewable energy systems are discussed, and a novel system is presented by coupling renewable energy sources.

\section{Energy conversion devices for micro- CHP}

The conversion devices for the micro-CHP systems can be divided into categories that are presented in Fig.1.

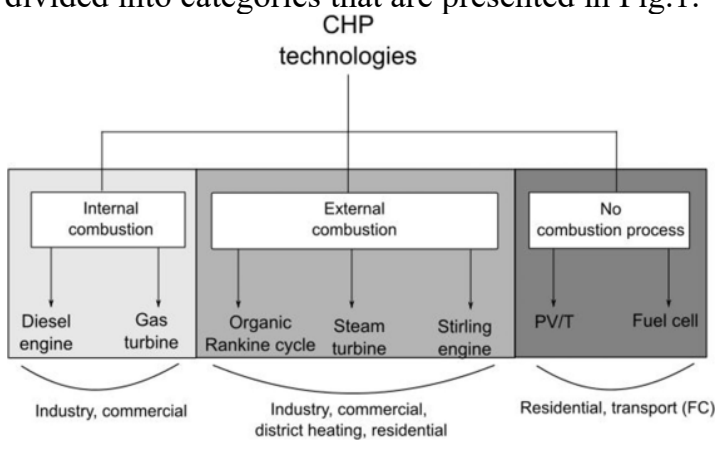

Fig. 1. The main conversion technologies for micro-CHP. [3]

The most commonly used technology is combustion based micro-CHP system. The external combustionbased systems have better fuel adaptability to use different renewable sources. [3] The third category

Corresponding author: sonja.kallio@insa-strasbourg.fr 
includes solar-based photovoltaic-thermal and fuel cell cogeneration. Additionally, thermoelectric generators (TEGs) can be counted to the third category. The TEG converts heat at high temperature into electrical power and low-temperature heat without moving parts or working fluid. [2] The PVT technology is relatively new in the micro-CHP context.

In terms of micro-cogeneration, the main renewable energy sources are biomass, biofuel and solar. [3] In Fig. 2 are presented the main sources of the biomass.

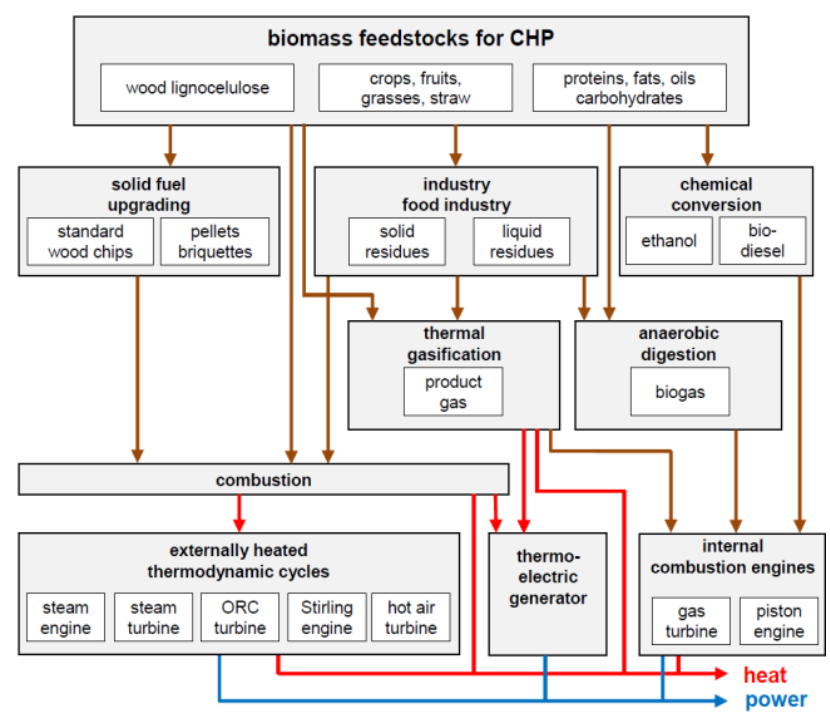

Fig. 2. The different ways to process biomass for CHP. [2]

Figure 2 shows that the external combustion engines are more flexible in terms of solid biomass fuels. In terms of micro-CHP, the most used biomass fuels are wood pellets. In addition to fossil fuels, the internal combustion engines, gas turbines and fuel cells can be turned into a renewable energy source and be fuelled by biodiesel or -gas. The TEGs use hot gases from combustion or thermal gasification as a heat source.

This paper focuses on the following externally fired solid biomass-fuelled micro-CHP technologies: the Stirling engine, organic Rankine cycle, steam engine, and solar-based photovoltaic-thermal collectors.

\subsection{Stirling engine}

The Stirling engine (SE) belongs to the external combustion engines, and its operation happens in a closed and regenerative thermodynamic cycle. The SE consists of a piston, cylinder, displacer and regenerator. The hot flue gas from the external combustion process maintains the hot end of the cylinder at high temperature. The heat is removed to the working fluid (helium, hydrogen or air) by the hot end heat exchanger. Due to the expansion, the heated working fluid moves through the regenerator to the cold end of the cylinder and removes the heat to a sink. The cooled fluid is compressed by the displacer piston. At the same time, mechanical work is generated by the cyclic compression and expansion of the working gas acting on the piston. $[3,11]$
The Stirling engines are classified into kinematic and dynamic types as shown in Fig. 3. [12]

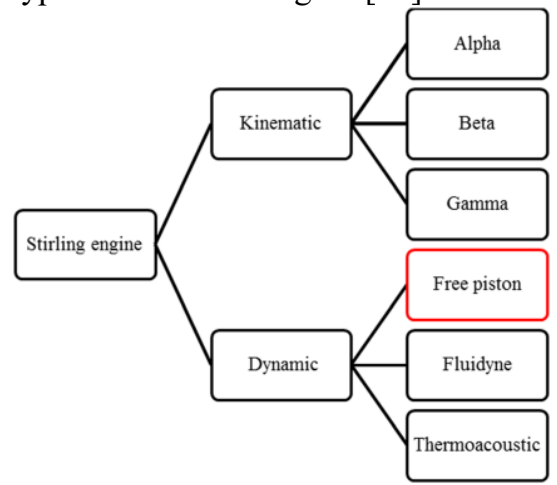

Fig. 3. The classification of the Stirling engines. [12]

The SE driven micro-CHP systems are mainly based on the two principal types: kinematic or free-piston. On the market, ÖkoFEN provides biomass-fuelled free-piston SE micro-CHP systems. [2] In Fig. 4 is shown a biomass-fuelled micro-CHP with an alpha type.

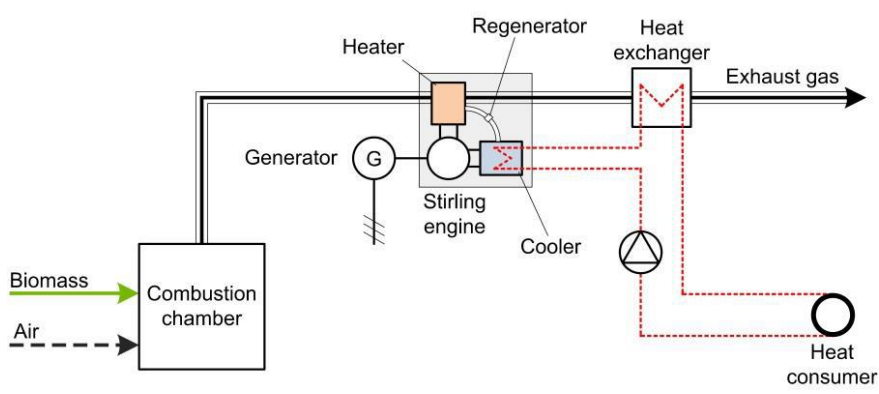

Fig. 4. The biomass fuelled micro-CHP with an alpha type. [2]

From the residential application point of view, the SE based micro-CHP systems have following advantages: the simple design of the engine, low maintenance requirements, low noise and vibration, fuel flexibility, and low emission level because of the external combustion. $[2,3,11]$

\subsection{Organic Rankine cycle}

The main components of the organic Rankine cycle (ORC) are evaporator, expander, condenser and feedpump. In the ORC an organic medium, such as Isopentane, Iso-octane, toluene or silicone oil, is used as working fluid. The produced heat from the combustion process is transferred to the evaporator through the heat transfer circuit (thermal oil or water). The high-pressure organic working fluid is vaporized in the evaporator and afterwards expanded to lower pressure in the circuit integrated turbine, which is connected to the generator to produce power. A heat sink recovers heat from the working fluid in the condenser after the expander. [2,3] The basic schematic of the ORC is presented in Fig. 5. The efficiency can be increased by adding a regenerator to the working fluid circuit and an economizer to the cooling circuit. [2] 


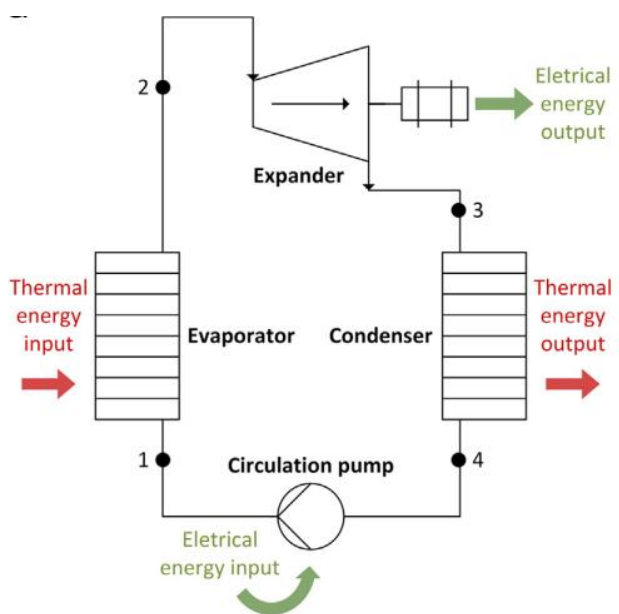

Fig. 5. The basic schematic representation of the ORC. [4]

The organic working fluid can be vaporized at lower temperatures and pressures compared to water. This enables the usage of low-temperature heat sources, such as biomass, waste heat and solar energy. [2]

In terms of residential building applications, the ORC micro-CHP systems have the following advantages: the fast response to the highly variable thermal load, lowcomplexity of the power cycle and low maintenance requirements. Additionally, the low activation temperatures between $75-90{ }^{\circ} \mathrm{C}$ can be used with high efficiency. $[2,4]$

The Rankine cycle has been developed since 1980s and is well deployed in the large scale industrial CHP systems. [3] However, in terms of micro-CHP systems, the main challenge of the ORC lies in the downscaling of the design and construction of the expander by maintaining still good performance. [2] Pereira et al. [4] presented a review on the ORC micro-CHP systems for residential applications and current challenges. They found that the focus should be in the ORC-evaporator design and how the primary energy is transferred to the power cycle to meet the variable thermal load. On the market, the Rank Company provides successfully microscale ORC systems with different fuels. Their microORC system can be run with the inlet temperature range $90-120^{\circ} \mathrm{C}$ and can work still efficiently with $50 \%$ partial load. [13]

\subsection{Steam engine}

The principle of the steam engine cycle is the same as for the ORC, but a steam piston engine is used to expand the steam. Figure 6 presents the operating principle of the steam piston engine. The steam runs to the engine and expands (picture a). The expansion forces the piston down (picture b) and the volume of the steam increases and pressure decreases. Finally, the piston moves back to the top, and the exhaust steam flows out of the cylinder for the heat recovery circuit. [2]

The main advantages of the steam engine are simplicity of the system, cheap design, long lifetime and fuel flexibility concerning biomass, biogas or solar energy. Additionally, it can operate with saturated steam and is highly insensitive to fluctuating steam quality.
However, the steam engine requires constant maintenance and is noisy. [2,14]

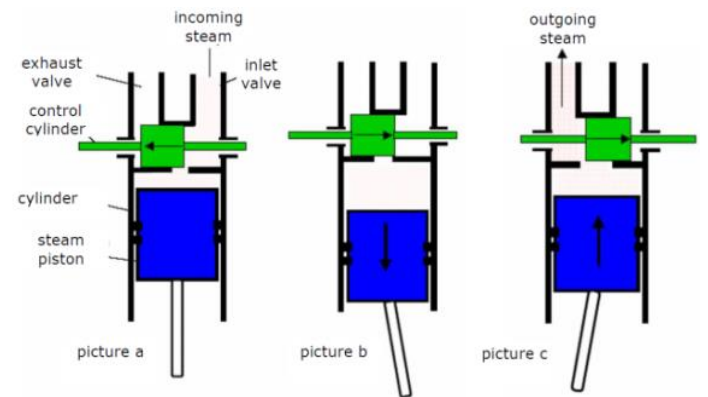

Fig. 6. Operating principle of the steam piston engine. [2]

Bouvenot et al. [14] investigated experimentally biomass-fuelled steam engine micro-CHP system presented in Fig. 7. The system was modelled and experimentally validated. The system reached the maximum electrical efficiency of $9 \%$ and the global efficiency of $95 \%$ at full load operation.

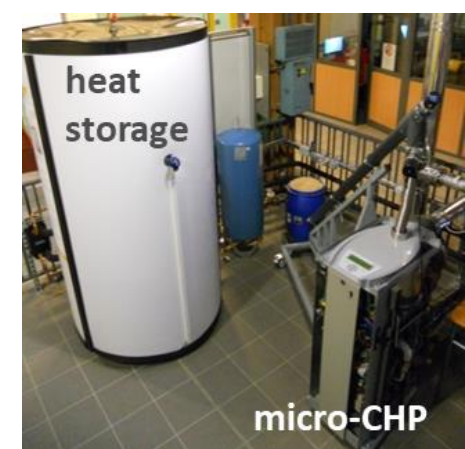

Fig. 7. Steam engine experimental set-up. [14]

Bouvier et al. [15] conducted an experimental characterisation of the solar micro-CHP system based on a SE. The solar parabolic trough collectors were used to produce steam for the engine, and the electrical power of $1.4 \mathrm{~kW}$ and thermal $18.3 \mathrm{~kW}$ were reached.

\subsection{Photovoltaic-thermal}

A photovoltaic-thermal (PVT) collector is a solar microCHP system which generates simultaneously heat and power from solar energy and the same installed area. It produces electricity by the PV module and useful heat by cooling the PV module with a coolant fluid, such as water. This leads to increased overall system efficiency but also to increased electrical efficiency due to the decreased operating temperature of the PV module. The PVT collectors have been widely studied in the literature [16-18]. In Fig. 8 is presented a covered water-based PVT collector.

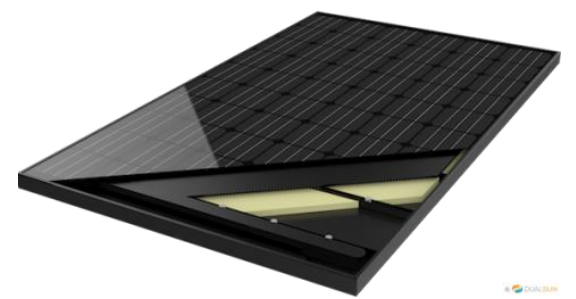


Fig. 8. The water-based flat plate PVT panel. Source: DualSun

The PVT collectors are well suited for the residential building sector for DHW production or space heating. On the market, the most common PVT collectors are flat plate type and air- or water-based that produce low-grade heat and electricity. They are glass-covered or coverless. The companies DualSun and Abora Solar are manufacturing successfully the high-efficiency flat plate water-based PVT collectors. With a solar array concentrator, the electrical and thermal efficiency of the PVT can be increased and the required installation area decreased. Additionally, the higher outlet temperatures of the cooling fluid can be reached which allows the wider range of applications. The company Naked Energy has developed a high energy-intensive PVT collector based on a vacuum tube and concentrator with fewer space requirements. They have just entered the market and are seen as a game-changer.

\section{Hybrid renewable energy systems}

The hybrid renewable energy systems (HRES) are defined as the combination of two or more renewable energy sources. [19] The particularly interesting is the coupling the renewable energy based micro-CHP systems with each other, such as the PVT collectors with the biomass combustion. In this kind of hybrid system, the PVT collectors can be used to produce heat for DHW and electricity during the summer months and biomass combustion during the cooler period when heat demand is higher. Compared to a biomass micro-CHP alone, the proposed coupling can reduce primary energy use and $\mathrm{CO}_{2}$ emissions even more because of solar energy use.

Wang et al. [20] studied thermos-economic feasibility of a hybrid solar-biomass cogeneration system based on flat plate type PVT collectors and biomassfuelled ORC micro-CHP system integrated with thermal storage for a sport-centre application. The system is shown in Fig. 9. They found that integration of the solar increased significantly the electrical energy production capability.

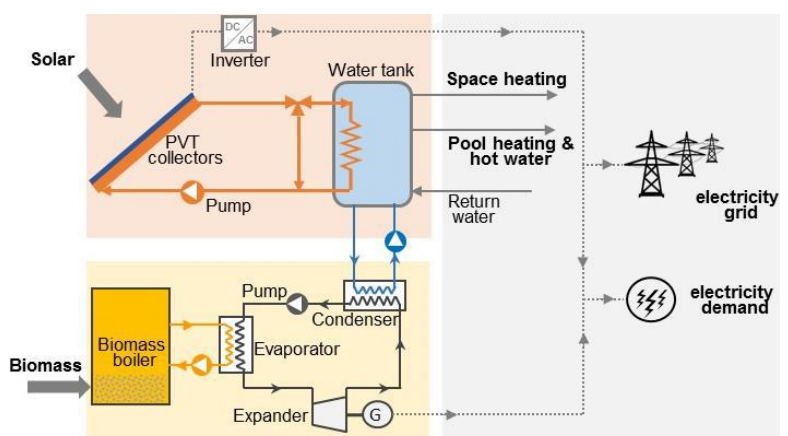

Fig. 9. Working principal of the PVT-ORC micro-CHP. [20]

Kosmadakis et al. [21] studied experimentally coupling of concentrating PVT collectors directly with the low-temperature ORC. Their tests revealed that the system can have sufficient efficiency; the coupling with PVT increases power generation, and the system is feasible.
The company ÖkoFEN provides residential hybrid renewable energy systems. The system, called Pellematic Smart XS, consists of the flat plate PVT collectors and high efficient biomass boiler with heat storage. The other provided hybrid system is called myEnergy365, which integrates a SE micro-CHP called Pellematic Condes_e, $\mathrm{PV}$ panels and energy storages. The produced energy is $100 \%$ renewable and enables $100 \%$ self-sufficiency. Both systems are equipped with the intelligent regulation system, which has a key role in the hybrid energy system. Replacing the PV panels by PVT panels in myEnergy365 system would increase the initial investment costs, but the energetic and environmental benefits should be further investigated.

Based on the conducted review, a novel hybrid renewable energy system is proposed. This highefficiency hybrid system consists of the ORC based micro-CHP unit fuelled by high energy-intensive PVT collectors and a biomass boiler. The benefits of the proposed system are: running the ORC is continues, $100 \%$ renewable energy and self-sufficiency, using PVT increases electricity production and reduces fuel consumption, biomass boiler ensures the heat and electricity production during less sunny periods. The system is suitable for residential use and does not require a high amount of direct solar radiation.

The proposed micro-scale system requires more investigation. The similar hybrid systems have been studied in the industrial scale by combining conventional Concentrating Solar Power (CSP) and biomass power plants. The results showed decrease in Levelized Cost of Electricity due to reduced solar field size and biomass costs. The plant capacity utilization was also increased significantly. [22]

\section{Conclusions}

To reach the primary energy and emissions reduction targets of the EU, heat and power has to be produced with more efficient and environmentally friendly systems. The building sector is the largest energy enduse sector in the EU with a share of $41 \%$. [1] The microCHP systems can operate with a total efficiency of 75 $95 \%$. [3] These systems are playing a key role to reduce emissions and energy use in the residential building sector.

Different technologies are available for renewable micro-CHP systems. In this review, the biomass and solar fuelled technologies are considered: Stirling engine, ORC, steam engine and PVT collectors. The literature shows that the Stirling engine and PVT micro-CHP systems are the most advanced in terms of residential applications. The ORC and SE systems have a benefit of using low-grade heat for the activation of the cycle and have a high potential for the residential applications. However, the initial investment costs should be reduced to ensure market penetration.

The hybrid energy systems are the only way to produce continuously $100 \%$ renewable energy and to reach $100 \%$ self-sufficiency with renewable energy. In conclusion, the literature and market situation shows that 
hybrid renewable energy systems are attractive and already have an industrial reality.

In future work, as a first step, the coupling of the flat plate PVT collectors with the biomass-fuelled Stirling micro-CHP unit will be studied from energy, exergy and economic point of view. The hybrid renewable energy system will be extended with energy storages. As a next step, the proposed solar and biomass fuelled ORC-based micro-CHP system on the building sector will be studied.

The authors would like to thank Interreg V Rhin supérieur for their support and funding of this research.

\section{References}

1. E. Doroudchi, K. Alanne, Ö. Okur, J. Kyyrä, M. Lehtonen, Approaching net zero energy housing through integrated EV. Sustain. Cities Soc. 38 (2018), 534-542

2. R. Padinger, S. Aigenbauer, C. Schmidl, Best practise report on decentralized biomass fired CHP plants and status of biomass fired small-and micro scale CHP technologies. IEA Bioenergy, 32 (2019)

3. S. Martinez, G. Michaux, P. Salagnac, J.L. Bouvier, Micro-combined heat and power systems (microCHP) based on renewable energy sources. Energy Convers. Manag., 154 (2017), 262-285.

4. J.S. Pereira, J.B. Ribeiro, R. Mendes, G.C. Vaz, J.C. André, ORC based micro-cogeneration systems for residential application - A state of the art review and current challenges. Renew. Sustain. Energy Rev., 92 (2018), 728-743

5. S. Martinez, G. Michaux, P. Salagnac, J. Faure, Numerical Investigation of Energy Potential and Performance of a Residential Building- Integrated Solar - Chp System. (2018), 1-20

6. S. Murugan, B. Horák, A review of micro combined heat and power systems for residential applications. Renew. Sustain. Energy Rev., 64 (2016), 144-162

7. I. González-Pino, E. Pérez-Iribarren, A. CamposCelador, J. Terés-Zubiaga, J. Las-Heras-Casas, Modelling and experimental characterization of a Stirling engine-based domestic micro-CHP device. Energy Convers. Manag., 225 (2020)

8. A. Modi, F. Bühler, J.G. Andreasen, F. Haglind, A review of solar energy based heat and power generation systems. Renew. Sustain. Energy Rev., 67 (2017), 1047-1064

9. P. Cheekatamarla, A. Abu-Heiba, A Comprehensive Review and Qualitative Analysis of MicroCombined Heat and Power Modeling Approaches. Energies, 13 (2020)
10. I. Beausoleil-Morrison, An Experimental and Simulation-Based Investigation of the Performance of Small-Scale Fuel Cell and Combustion-Based Cogeneration Devices Serving Residential Buildings, Final Report of Annex 42 of IEA, (2008)

11. P.J. Zabalaga, E. Cardozo, L.A.C. Campero, J.A.A. Ramos, Performance analysis of a stirling engine hybrid power system. Energies, 13, (2020)

12. S. Zare, A. Tavakolpour - Saleh, Free piston Stirling engines: A review. Int. J. Energy Res., 44 (2020), 5039-5070

13. Rank. Available online: https://www.rankorc.com/rank-micro-2/ (accessed on Nov 2, 2020).

14. J.B. Bouvenot, B. Latour, M. Siroux, B. Flament, P. Stabat, D. Marchio, Dynamic model based on experimental investigations of a wood pellet steam engine micro CHP for building energy simulation. Appl. Therm. Eng., 73 (2014), 1041-1054

15. J.L. Bouvier, G. Michaux, P. Salagnac, F. Nepveu, D. Rochier, T. Kientz, Experimental characterisation of a solar parabolic trough collector used in a microCHP (micro-cogeneration) system with direct steam generation. Energy, 83 (2015), 474-485

16. M. Herrando, A. Ramos, J. Freeman, I. Zabalza, C.N. Markides, Technoeconomic modelling and optimisation of solar combined heat and power systems based on flat-box PVT collectors for domestic applications. Energy Convers. Manag., 175 (2018), 67-85

17. M. Barbu, G. Darie, M. Siroux, Analysis of a residential photovoltaic-thermal (PVT) system in two similar climate conditions. Energies, 12 (2019), $1-18$

18. S. Kallio, M. Siroux, Energy Analysis and Exergy Optimization of Photovoltaic-Thermal Collector. Energies, 13 (2020), 5106

19. K. Shivarama Krishna, K. Sathish Kumar, A review on hybrid renewable energy systems. Renew. Sustain. Energy Rev., 52 (2015), 907-916

20. K. Wang, A.M. Pantaleo, O.A. Oyewunmi, C.N. Markides, Flexible PVT-ORC hybrid solar-biomass cogeneration systems: the case study of the university sports centre in Bari, Italy. (2019), 1-9

21. G. Kosmadakis, A. Landelle, M. Lazova, D. Manolakos, A. Kaya, H. Huisseune, C.S. Karavas, N. Tauveron, R. Revellin, P. Haberschill, et al. Experimental testing of a low-temperature organic Rankine cycle (ORC) engine coupled with concentrating PV/thermal collectors: Laboratory and field tests. Energy, 117 (2016), 222-236

22. N.S. Suresh, N.C. Thirumalai, S. Dasappa, Modeling and analysis of solar thermal and biomass hybrid power plants. Appl. Therm. Eng., 160 (2019) 